\title{
Pathogenicity of Phytophthora capsici to Brassica Vegetable Crops and Biofumigation Cover Crops (Brassica spp.)
}

Charles S. Krasnow and Mary K. Hausbeck, Department of Plant, Soil, and Microbial Sciences, Michigan State University, East Lansing, 48824

\begin{abstract}
Krasnow, C. S., and Hausbeck, M. K. 2015. Pathogenicity of Phytophthora capsici to Brassica vegetable crops and biofumigation cover crops (Brassica spp.). Plant Dis. 99:1721-1726.

The soilborne oomycete Phytophthora capsici causes root, crown, and fruit rot of many vegetable crops in the Cucurbitaceae and Solanaceae families. $P$. capsici is a persistent problem in vegetable fields due to long-lived oospores that survive in soil and resist weathering and degradation. Vegetable crops in the Brassicaceae family have been considered nonhosts of $P$. capsici and are planted as rotational crops in infested fields. Brassica spp. are also grown as biofumigation cover crops to reduce inoculum levels of P. capsici and other soilborne pathogens, and this use has increased concurrent with restrictions on soil fumigation. Oriental mustard (Brassica juncea), oilseed rape (B. napus), and oilseed radish (Raphanus sativus var. oleiferus) contain high levels of glucosinolates and are widely recommended for biofumigation and as cover crops.

The objective of this study was to evaluate vegetables and biofumigation cover crops in the Brassicaceae family for susceptibility to $P$. capsici. Brassica spp. used as vegetable crops and for biofumigation were grown in $P$. capsici-infested potting soil in the greenhouse and disease incidence and severity were recorded. In greenhouse trials, infection by the pathogen reduced the fresh weight of all Brassica spp. tested and resulted in plant death of $44 \%$ of plants of $B$. juncea 'Pacific Gold'. P. capsici isolates exhibited differences in virulence $(P<0.0001)$, and were reisolated from the roots of all Brassica spp. included in the study. The biofumigation cover crop Pacific Gold mustard may not reduce populations of $P$. capsici in soil and, instead, may sustain or increase pathogen levels. Further research is necessary to test this possibility under field conditions.
\end{abstract}

The Brassicaceae family includes vegetables and cover crops considered important due to their diversity and adaptability to variable soil types and growing conditions (Nieuwhof 1969). In Michigan, over 2,500 ha of cabbage, turnip, radish, broccoli, and other Brassica vegetables are grown annually for the fresh and processing markets (Anonymous 2012). In addition to production as vegetable crops, Brassica spp. are widely planted as cover crops and for biofumigation in both horticultural and agronomic crop production (Kirkegaard and Sarwar 1998; Ngouajio and Mutch 2004; Snapp et al. 2006). Numerous studies have reported that Brassica biofumigation can reduce soilborne pathogens that are often an intractable problem in both conventional and organic vegetable production (Lewis and Papaviza 1971; Mattner et al. 2008; Mayton et al. 1996; Muehlchen et al. 1990). The use of Brassica spp. for this purpose has increased in recent years concurrent with the phase-out of the fumigant methyl bromide and an emphasis on sustainable disease management alternatives (Ackroyd 2010; Gardiner et al. 1999; Kirkegaard and Sarwar 1998; Lazzeri and Manici 2001). The ability of Brassica spp. to reduce pathogen inoculum density is attributed to glucosinolates, which are hydrophilic, thioglucoside compounds that are stored in the cell vacuoles of all Brassica spp. for use in sulfur assimilation and storage (Clossais-Besnard and Larher 1991; Larsen 1980; Marschner 1995). At vegetative maturity, Brassica cover crops are incorporated into the soil via flail mowing and disking, and the disruption of cellular content facilitates the hydrolysis of glucosinolates by the enzyme myrosinase (Fahn 1982; Marschner 1995; Morra and Kirkegaard 2002). Volatile isothiocyanates and other hydrolysis products that possess biocidal properties are produced during this process (Kirkegaard and Sarwar 1998; Larsen 1980; Smolinska et al. 1997) and come into

Corresponding author: M. K. Hausbeck; E-mail: hausbec1@ msu.edu

Accepted for publication 24 May 2015.

http://dx.doi.org/10.1094/PDIS-03-15-0271-RE

This article is in the public domain and not copyrightable. It may be freely reprinted with customary crediting of the source. The American Phytopathological Society, 2015. direct contact with pathogen propagules following soil incorporation (Lazzeri and Manici 2001; Lewis and Papaviza 1971; Snapp et al. 2006). Certain Brassica varieties have been developed and marketed specifically for the quantity and composition of glucosinolates produced by the plant (Anonymous 2014; Baysal and Miller 2009; Charron and Sams 1999; Morra and Kirkegaard 2002). Disease control recommendations using Brassica biofumigation have not been optimized, however, because glucosinolate production is environmentally and ontogenetically influenced (Greenhalgh and Mitchell 1976; He et al. 2003; McGregor 1988; Rosa et al. 1996; Sarwar and Kirkegaard 1998).

Phytophthora root and crown rot of Brassica crops caused by Phytophthora drechsleri and P. megasperma has been reported on cabbage, broccoli, cauliflower, and turnip, and occasionally causes major economic loss (Downes and Loughnane 1969; Geeson et al. 1990; Hamm and Koepsell 1984; Tompkins et al. 1936). Symptoms typical of Phytophthora root rot of Brassica crops include wilt, purple discoloration of the stem and older foliage, and eventual plant death (Downes and Loughnane 1969; Tompkins et al. 1936). Phytophthora spp. also cause postharvest rots during storage of cabbage, Chinese cabbage, and swede (Geeson 1976; Geeson et al. 1990; Hermansen and Hoftun 2005; Semb 1969). Management practices to control Phytophthora rots affecting Brassica spp. include planting into well-drained soil, fungicide application, and temperature control postharvest (Hermansen and Hoftun 2005; Kontaxis and Rubatzky 1983). P. capsici has been reported to be pathogenic to seedlings of cauliflower, radish, and turnip in studies conducted under controlled environmental conditions (Hartman and Huang 1993; Ji et al. 2012; Satour and Butler 1967; Tian and Babadoost 2004). In the same studies, $P$. capsici was nonpathogenic on cabbage, broccoli, mustard, rape, kale, and kohlrabi. Reports of $P$. capsici affecting traditional nonhost crops, including Fraser fir (Quesada-Ocampo et al. 2009), herbaceous ornamental plants (Enzenbacher 2011), snap bean (Gevens et al. 2008), and weed species such as Portulaca oleracea (French-Monar et al. 2006), highlight this pathogen's virulence and adaptability to diverse hosts. $P$. capsici is known to increase in virulence as a result of genetic exchange during oospore formation (Satour and Butler 1968), and the frequent occurrence of both mating types in vegetable fields (Lamour and Hausbeck 2000) heightens the importance of control methods to reduce inoculum pressure and 
pathogen spread. Brassica vegetables such as cabbage, broccoli, and radish, and Brassica spp. used for biofumigation, are often planted into fields infested with $P$. capsici with the assumption that these crops are not affected by the pathogen and will reduce inoculum levels (M. K. Hausbeck, personal communication). The potential for $P$. capsici to cause disease on Brassica spp. or to survive and reproduce in debris remaining in the field postharvest would negatively affect growers facing limited crop rotation, fumigation, and fungicide control options (Hausbeck and Lamour 2004). The objective of this study was to evaluate select vegetables and biofumigation cover crops in the Brassicaceae family for susceptibility to P. capsici.

\section{Materials and Methods}

Isolate selection and inoculum preparation. $P$. capsici isolates originally collected from cucurbitaceous, solanaceous, and fabaceous hosts were selected from the culture collection of Dr. M. K. Hausbeck. The isolates were previously characterized for mating type (MT) and mefenoxam sensitivity (Lamour and Hausbeck 2000). Isolate 12889 (A1 MT) is mefenoxam insensitive and 10193 (A1 MT) and 14110 (A2 MT) are mefenoxam sensitive. The cultures were maintained on V8 agar media (143 $\mathrm{ml}$ of V8 juice, $3 \mathrm{~g}$ of $\mathrm{CaCO}_{3}, 16 \mathrm{~g}$ of agar, and $850 \mathrm{ml}$ of distilled water). Prior to the study, the isolates were inoculated onto pepper fruit and subsequently recovered from the diseased fruit to ensure virulence of the isolates (Quesada-Ocampo and Hausbeck 2010). Millet inoculum (Quesada-Ocampo and Hausbeck 2010) was prepared by autoclaving millet seed $(100 \mathrm{~g})$, distilled water $(72 \mathrm{ml})$, and L-asparagine $(0.08 \mathrm{mg})$ in mushroom bags (RJG Sales, Port Richey, FL) twice consecutively, and adding seven 7-mm agar plugs colonized by a single $P$. capsici isolate. Infested millet seed was grown under constant fluorescent light for 3 to 4 weeks and mixed weekly prior to use as inoculum.

Pathogenicity testing of $\boldsymbol{P}$. capsici on Brassica spp. Brassica vegetables and cover crops (Table 1) were sown into 288-cell flats in the Plant Science Research Greenhouses at Michigan State University, East Lansing. Millet ( $3 \mathrm{~g}$ ) infested with a single isolate and prepared as described previously was deposited into each transplant hole in $10-\mathrm{cm}$ pots containing autoclaved peat potting mixture (Suremix Michigan Grower Products Inc., Galesburg, MI) and gently

Table 1. Brassica spp. used as vegetables and biofumigation cover crops evaluated in Phytophthora capsici pathogenicity experiments

\begin{tabular}{|c|c|c|c|}
\hline Brassica spp. & Cultivar & Intended use & $\begin{array}{l}\text { Days to } \\
\text { maturity }\end{array}$ \\
\hline \multicolumn{4}{|l|}{ Brassica juncea $\mathrm{L}$. } \\
\hline Mustard & $\begin{array}{l}\text { Florida Broad } \\
\text { Leaf }^{\mathrm{a}}\end{array}$ & Fresh market & 40 \\
\hline Indian mustard & Pacific Gold ${ }^{\mathrm{b}}$ & Biofumigation & $65-80$ \\
\hline \multicolumn{4}{|l|}{ B. napus } \\
\hline Rape & Dwarf Essex ${ }^{b}$ & Biofumigation $^{\mathrm{d}}$ & $60-80$ \\
\hline \multicolumn{4}{|c|}{ B. oleracea var. botrytis } \\
\hline Cauliflower & Snow Crown ${ }^{\mathrm{c}}$ & Fresh market & 50 \\
\hline \multicolumn{4}{|c|}{ B. oleracea var. capitata } \\
\hline Green cabbage & Bronco $^{c}$ & Fresh market & 78 \\
\hline Red cabbage & Buscaro $^{c}$ & $\begin{array}{l}\text { Fresh market/ } \\
\text { processing }\end{array}$ & 100 \\
\hline \multicolumn{4}{|c|}{ B. oleracea var. italica } \\
\hline Broccoli & Emerald Crown ${ }^{\mathrm{c}}$ & Fresh market & 60 \\
\hline \multicolumn{4}{|l|}{ B. rapa } \\
\hline Turnip & $\begin{array}{l}\text { Purple Top } \\
\text { White Globe }\end{array}$ & Fresh market & 58 \\
\hline \multicolumn{4}{|l|}{ Raphanus sativus } \\
\hline Radish & Rover $^{\mathrm{c}}$ & Fresh market & 25 \\
\hline \multicolumn{4}{|c|}{ R. sativus var. oleiferus } \\
\hline Oilseed radish & Groundhog ${ }^{\mathrm{c}}$ & Biofumigation $^{\mathrm{d}}$ & $60-90$ \\
\hline $\begin{array}{l}\text { a Rispens Seeds, I } \\
\text { b Johnny's Selecte } \\
\text { c Seedway, Penns } \\
\text { d Oilseed radish } \\
\text { mowing and inc } \\
\text { biofumigation. }\end{array}$ & $\begin{array}{l}\text { Maine. } \\
\text { e also used as } \\
\text { of green tissue }\end{array}$ & tional cover & 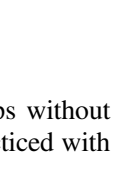 \\
\hline
\end{tabular}

mixed to incorporate with the soil. Eight-day-old seedlings were used for the study and were transplanted into the infested peat potting mixture. Control pots received $3 \mathrm{~g}$ of millet prepared with sterile V8 agar plugs. The quantity of inoculum was selected based on previous studies (Quesada-Ocampo et al. 2009) and preliminary inoculum-density experiments with 'Bronco' cabbage (data not shown). A single plant was grown in each pot and was considered an experimental unit, with six pots per isolate for each cultivar. All plants in the experiment were inoculated on the same day. Plants were watered to maintain adequate soil moisture, and plant height from the soil-line to the tallest expanded foliage and width at the widest point were measured weekly during the experiment. Visual disease severity was rated on a 0 -to-4 scale adapted from Glosier et al. (2008), where $0=$ healthy; $1=$ minor wilting, chlorosis, or stunting; 2 = moderate wilting, chlorosis, and stunting; 3 = severe wilting, chlorosis, and stunting; and 4 = plant death. Plants of 'Pacific Gold' and 'Florida Broad Leaf' mustard and 'Rover' and 'Groundhog' radish were harvested 3 weeks after inoculation, and all other crops were harvested 4 weeks after inoculation. Aboveground fresh weights were recorded at harvest for all crops. Root weights of Groundhog and Rover radish and 'Purple Top White Globe' turnip were also recorded. At the completion of the experiment, roots were rinsed in tap water to remove adhering potting mix and approximately 50\% of the plants of each cultivar and isolate were arbitrarily selected for pathogen reisolation. $\mathrm{Ne}$ crotic or water-soaked root tissue was rinsed in sterile distilled water and surface sterilized in $70 \%$ ethanol for $5 \mathrm{~s}$ prior to plating onto V8 agar amended with benomyl at $50 \mathrm{ppm}$, pentachloronitrobenzene at $100 \mathrm{ppm}$, ampicillin at $100 \mathrm{ppm}$, and rifampicin at $30 \mathrm{ppm}$. Isolated colonies were transferred to V8 agar and confirmed as $P$. capsici by pathogen morphology (Waterhouse 1963). Temperature and relative humidity were measured using a WatchDog data logger (Spectrum Technologies Inc., Plainfield, IL). The experiment was organized in a completely randomized design and was conducted twice.

Statistical analysis. Data were analyzed using SAS (version 9.4; SAS Institute, Cary, NC). Response variables were analyzed by analysis of variance (ANOVA) using the Proc Mixed procedure. $P$. capsici isolate and cultivar were considered fixed variables and trials were considered random variables. Interactions were sliced when found to be significant at $P=0.05$ in an ANOVA to analyze simple main effects. The response variables fresh weight, root weight, plant height, and plant width were analyzed separately for each cultivar. Fisher's protected least significant difference was used to separate treatment differences using the SAS pdmix 800 macro (Saxton 1998). Residuals were plotted against predicted values using Proc Gplot and checked for normality and equal variance to ensure that statistical assumptions were met. Data from noninoculated control plants were not included in the analysis because disease symptoms were not observed and root isolations did not yield $P$. capsici. Pearson's correlation coefficients between incidence of disease and the independent variables plant height, width, and aboveground weight were analyzed using Proc Corr to determine the degree of association between disease incidence and plant size. The likelihood of disease incidence due to specific isolates was analyzed using logistic regression.

\section{Results}

Disease symptoms observed for inoculated Brassica plants included stunting, wilting, chlorosis, and plant death (Fig. 1). Severely affected cauliflower and broccoli plants also exhibited purple discoloration of the foliage. Initial symptoms of wilting and chlorosis were typically evident within 3 days postinoculation. Discolored roots and constriction of the stem at the soil line were apparent upon harvest of symptomatic plants. The results were similar between the two trials and data were pooled for analysis because a significant trialtreatment interaction was accounted for by magnitude of plant growth, not rank. Differences in temperature and relative humidity were observed between the two experiments, with a mean temperature and relative humidity of $26.6^{\circ} \mathrm{C}$ and $19 \%$ in trial 1 and $29.4^{\circ} \mathrm{C}$ and $41 \%$ in trial 2.

Disease symptoms were noted on all inoculated Brassica cultivars included in this study (Table 2). There was a negative correlation 
between fresh weight and disease incidence for all cultivars $\left(R^{2}=\right.$ $-0.391, P<0.0001)$ and a similar correlation with height and width measurements was observed (data not shown). Using logistic regression, the probability of disease incidence was highest in Pacific Gold $(P<0.0001)$ and lowest in 'Dwarf Essex' $(P=0.79)$. Dwarf Essex displayed the lowest disease severity when compared with the other Brassica spp. (Table 2). The Brassica spp. used for biofumigation tended to exhibit a more drastic decrease in fresh weight than the vegetable crops (Table 3); for example, Pacific Gold and Groundhog displayed a 78 and $24 \%$ reduction, respectively, in fresh weight compared with the control $(P<0.001)$. The reduction in fresh weight for the Brassica spp. used as vegetable crops was significant for Bronco $(P<0.01)$ and 'Buscaro' $(P<0.05)$ cabbage, and was not significant for the remaining cultivars (Table 3 ). $P$. capsici also reduced root weight of the three Brassica spp. grown for their large root size $(P=0.1)$, most notably with Purple Top White Globe (Fig. 2).

The three $P$. capsici isolates selected for this study caused varying degrees of disease severity on the Brassica spp. tested. Differences in the cumulative disease severity values between isolates 14110 and 10193 for Rover and Pacific Gold and between isolates 14110 and 12889 for Purple Top White Globe were significant $(P<0.05$, data not shown). However, at the final disease severity rating, differences among isolates were not significant $(P=0.159$, Table 2$)$. Isolate 14110 was the most virulent isolate tested based on disease incidence $(P<0.001$, data not shown), as determined by binary logistic regression. All P. capsici isolates tested reduced the height of Pacific Gold plants $(P<0.001$, Fig. 3) whereas significant differences among $P$. capsici isolates and the control were not observed with Florida Broad Leaf $(P=0.213)$. The differences in mean disease severity among Brassica juncea cultivars were larger than differences observed among other crops of the same species (Table 2). P. capsici was successfully reisolated from the roots of all Brassica cultivars tested (Table 2). Each of the three isolates included in the study were successfully recovered from at least one infected plant in both trials (data not shown).

\section{Discussion}

Cover crops are often grown in annual vegetable production systems primarily to improve soil drainage, suppress weeds, increase soil organic matter, capture nutrients, and reduce erosion (Hartwig

Table 2. Disease severity of select Brassica spp. used as vegetables and biofumigation cover crops when inoculated with Phytophthora capsici in greenhouse trials and frequency of pathogen recovery from diseased roots

\begin{tabular}{lcccc}
\hline & \multicolumn{3}{c}{ Disease severity $^{\mathbf{a}}$} & \\
\cline { 2 - 4 } Cultivar & $\mathbf{1 0 1 9 3}$ & $\mathbf{1 2 8 8 9}$ & $\mathbf{1 4 1 1 0}$ & Recovery $^{\mathbf{b}}$ \\
\hline Bronco & 0.25 & 0.33 & 0.50 & +++ \\
Buscaro & 0.42 & 0.25 & 0.58 & +++ \\
Emerald Crown & 0.33 & 0.50 & 0.33 & + \\
Dwarf Essex & 0.25 & 0.17 & 0.08 & ++ \\
Florida Broad Leaf & 0.67 & 0.25 & 0.50 & ++ \\
Groundhog & 0.80 & 0.40 & 0.56 & + \\
Pacific Gold & 2.25 & 3.00 & 3.25 & ++ \\
Purple Top White Globe & 0.33 & 0.25 & 0.75 & ++ \\
Rover & 0.0 & 0.08 & 0.33 & + \\
Snow Crown & 0.58 & 0.33 & 0.42 & + \\
Mean & 0.59 & 0.56 & 0.73 & $\ldots$ \\
\hline
\end{tabular}

${ }^{a}$ Disease severity values for each $P$. capsici isolate represent final visual rating of inoculated plants using a 0 -to- 4 scale, where $0=$ healthy; $1=$ minor wilting, chlorosis, or stunting; $2=$ moderate wilting, chlorosis, and stunting; $3=$ severe wilting, chlorosis, and stunting; and $4=$ plant death. Values represent the mean of two trials, with six replications per trial. Disease was not observed on nor was $P$. capsici recovered from control plants, which were not included in the analysis. $P$. capsici isolates originally were recovered from three different host families. Isolate designation from the culture collection of Dr. M. K. Hausbeck.

b Frequency of $P$. capsici recovery from roots of diseased Brassica spp.: + = $<33 \%,++=33$ to $66 \%$, and $+++=>66 \%$ recovery. Percentage of recovery represents the mean of two trials with six replications per trial. and Ammon 2002). Brassica spp. developed for biofumigation are planted in vegetable production systems when an additional goal is to decrease populations of soilborne pathogens (Ackroyd 2010; Charron and Sams 1999; Ngouajio and Mutch 2004; Snapp et al. 2006). The cover crops are usually seeded, grown to vegetative maturity, and incorporated prior to planting an economically important vegetable crop, or planted postharvest and killed by freezing temperatures (Snapp et al. 2006; Sundermeier 2008). Our greenhouse study indicates that $P$. capsici can colonize the roots of diverse Brassica spp. and can cause plant death of Pacific Gold mustard (B. juncea) and Groundhog radish (Raphanus sativus var. oleiferus) used specifically for biofumigation. There have been conflicting studies about the ability of Brassica cover crops to suppress oomycete plant pathogens (Larkin and Griffin 2007; Mattner et al. 2008; Wiggins and Kinkel 2005). Wiggins and Kinkel (2005) did not find a significant difference in Phytophthora root rot of alfalfa planted into pots of infested field soil that had been cropped to and amended with chopped canola (B. napus) tissue 20 days prior or left fallow. Similarly, a commercial biofumigation cover crop mixture of $B$. napus and $B$. rapa that was mowed and incorporated at anthesis into field soil did not decrease the viability of $P$. cactorum that was buried in the soil for 3 days following Brassica incorporation. Growth of the isolates on selective media after recovery from the soil, however, was reduced by $20 \%$ compared with $P$. cactorum buried and recovered from fallowed soils (Mattner et al. 2008). Control of pathogenic Pythium and Aphanomyces spp. with Brassica tissue and associated glucosinolate compounds has been more consistent than with Phytophthora spp. (Charron and Sams 1999; Lazzeri and Manici 2001; Lewis and Papaviza 1971; Muehlchen et al. 1990; Smolinska et al. 1997), although lack of suppression of Pythium spp. has been noted in studies on apple replant disease (Mazzola et al. 2007, 2009). Studies on the biofumigation potential of Brassica spp. to P. capsici have reported decreases in pathogen populations or disease severity upon incorporation of fresh or dry Brassica residues into soil, potting mix, or other media (Cohen et al. 2008; Demirci and Dolar 2006; Fan et al. 2008; Ji et al. 2012; Ludwig et al. 2004; McGrath and Menasha 2013; Ppoyil 2011; Sanogo and Schaub 2012; Wang et al. 2014). In a greenhouse study, the proportion of 'Dickenson' pumpkin plants infected by $P$. capsici crown rot was limited by adding macerated Brassica tissue to the soil around the crown of inoculated seedlings (Ppoyil 2011). McGrath and Menasha (2013) and Ji et al. (2012) found that mustard cultivars used for biofumigation were able to reduce the incidence of Phytophthora blight of pumpkin and squash, respectively,

Table 3. Effect of Phytophthora capsici isolate on aboveground fresh weight of select Brassica spp. used as vegetables and biofumigation cover crops in greenhouse pathogenicity trials

\begin{tabular}{lcccc}
\hline & \multicolumn{4}{c}{ Reduction in fresh weight $(\%)^{\mathbf{a}}$} \\
\cline { 2 - 5 } Cultivar & $\mathbf{1 0 1 9 3}$ & $\mathbf{1 2 8 8 9}$ & $\mathbf{1 4 1 1 0}$ & Mean $^{\mathbf{b}}$ \\
\hline Bronco & 16 & 24 & 22 & $21^{* *}$ \\
Buscaro & 13 & 22 & 29 & $21^{*}$ \\
Emerald Crown & 11 & 17 & 15 & 14 \\
Dwarf Essex & 6 & 0 & 0 & 2 \\
Florida Broad Leaf & 19 & 4 & 10 & 11 \\
Groundhog & 37 & 11 & 23 & $24^{* *}$ \\
Pacific Gold & 66 & 78 & 90 & $78^{* *}$ \\
Purple Top White Globe & 17 & 3 & 19 & 13 \\
Rover & 0 & 13 & 2 & 5 \\
Snow Crown & 9 & 11 & 19 & 13
\end{tabular}

a Decrease in aboveground fresh weight (\%) for each P. capsici isolate compared with control plants. Fresh weight (grams) was measured at the conclusion of each trial. Values represent the mean of two trials, with six replications per trial. $P$. capsici isolates originally were recovered from three different host families. Isolate designation from the culture collection of Dr. M. K. Hausbeck.

b Asterisks * and ** indicate significant treatment differences at $P<0.05$ and 0.01 , respectively, according to Fisher's protected least significant difference test. 
in field trials where the mustard cover crops were incorporated prior to planting. Additionally, pepper seeded into $P$. capsici-infested soil amended with $B$. juncea seed meal had a $46 \%$ germination rate as opposed to $6.7 \%$ in the infested control (Cohen et al. 2008). The sensitivity of $P$. capsici to Brassica tissue observed in previous studies may be related to the use of isolated volatile compounds, extracts, seed meal produced from Brassicaceous tissues, and macerated plant material (Charron and Sams 1999; Demirci and Dolar 2006; Mazzola et al. 2009; Morales-Rodriguez et al. 2014; Ppoyil 2011; Smolinska et al. 1997) to decrease pathogen levels. Differences exist among Brassica spp. between aboveground tissue and roots in quantity and composition of glucosinolates, with root tissue and seedlings usually containing higher quantities than shoots (Gardiner et al. 1999; Kirkegaard and Sarwar 1998; Muehlchen et al. 1990; Rosa

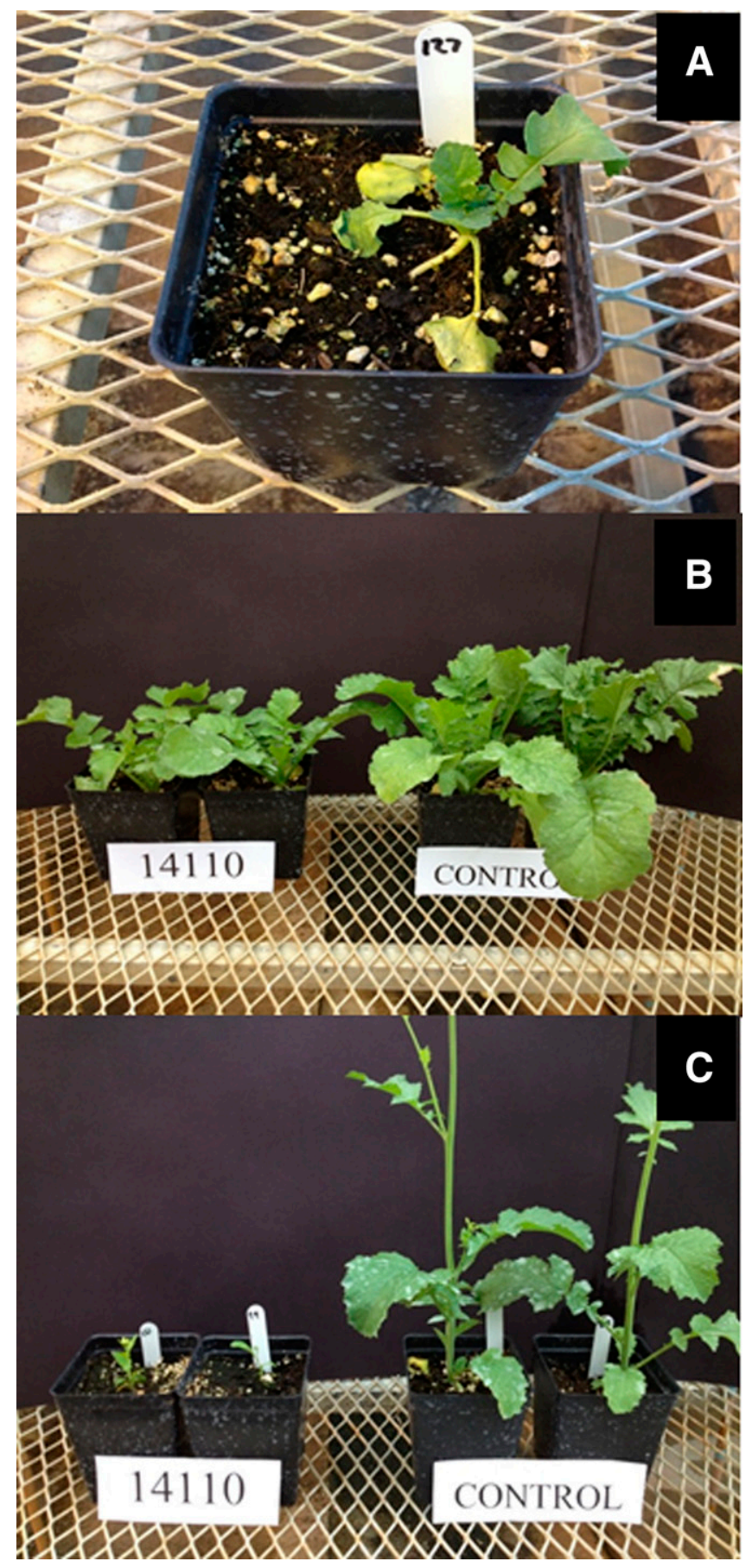

Fig. 1. Symptoms of disease caused by Phytophthora capsici on Brassica spp., including A, wilting of Groundhog radish; B, stunting of Groundhog radish; and C, plant death of Pacific Gold mustard.
1997). However, higher concentrations of glucosinolates in shoot tissue have been noted with Sinapis alba and B. juncea (Anonymous 2014). B. juncea cultivars, including Pacific Gold used in this study, contain the highest concentration of glucosinolate compounds among

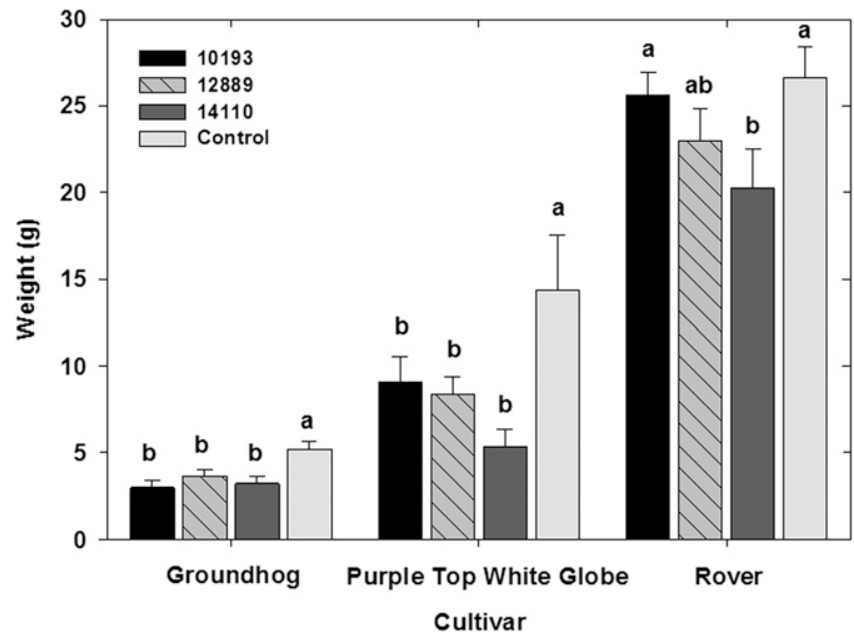

Fig. 2. Effect of Phytophthora capsici isolate on root weight of three Brassica cultivars grown for their large root size. Each column represents the mean of two trials, with six replicate plants per isolate per trial. Columns with a letter in common are not significantly different within each cultivar based on Fisher's protected least significant difference $(P<0.05)$. Error bars represent the standard error of the mean.
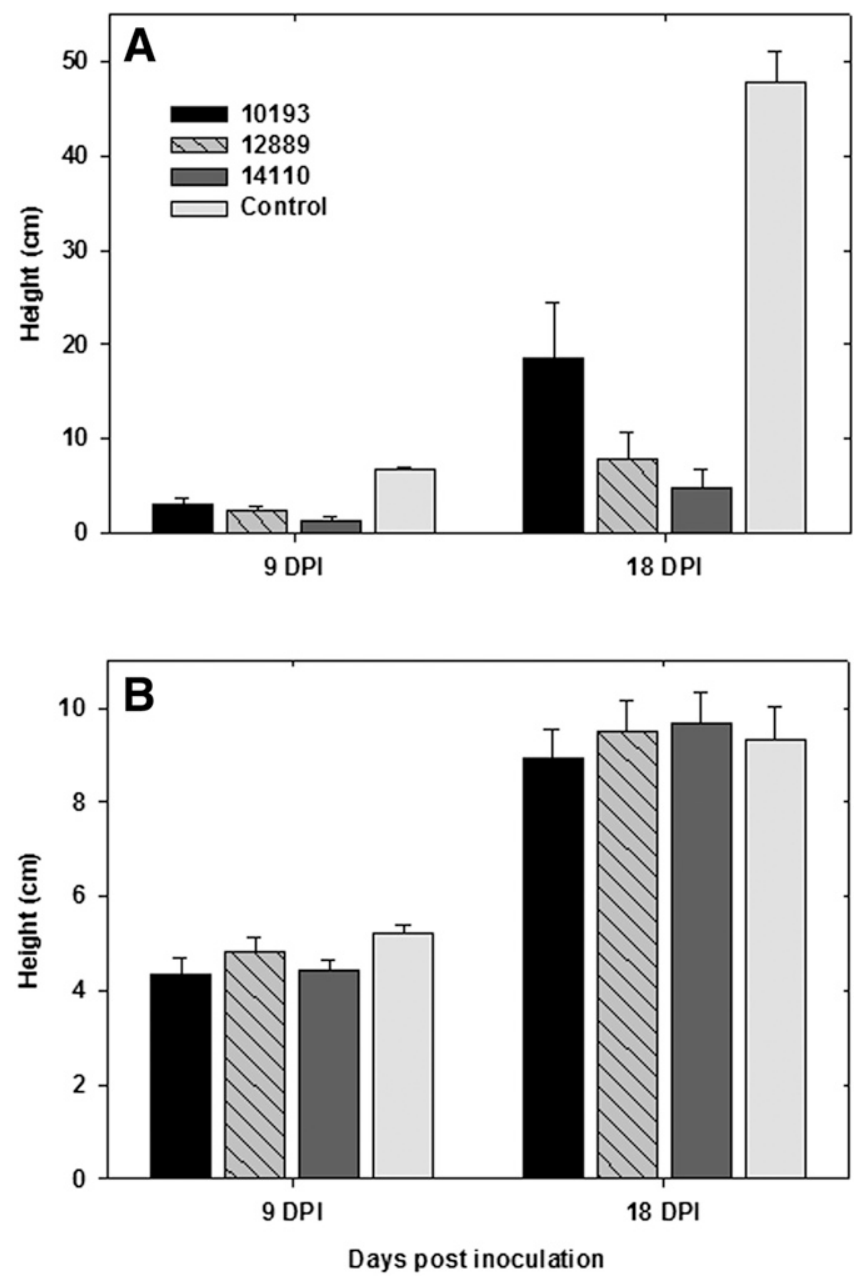

Fig. 3. Differences in height of A, Pacific Gold and B, Florida Broad Leaf at 9 and 18 days postinoculation (DPI) with three Phytophthora capsici isolates. Each column represents the mean of two trials, with six replicate plants per isolate per trial. Error bars represent the standard error of the mean. 
Brassica spp. used for biofumigation (Anonymous 2014; Charron and Sams 1999; Larkin and Griffin 2007; Smolinska and Horbowicz 1999; Snapp et al. 2006), and concentrations of glucosinolates are highest during the seedling stage (Fahey et al. 2001; He et al. 2003). Because Brassica spp. used for biofumigation and as cover crops are direct or broadcast seeded into vegetable production fields (Ngouajio and Mutch 2004; Sundermeier 2008), colonization of roots by $P$. capsici may increase pathogen populations in soil, nullifying the ability of glucosinolate compounds to significantly decrease pathogen levels. Additionally, $P$. capsici caused lesions on the foliage of seedlings and mature plants of cabbage, mustard, and other Brassica spp. when inoculated in the laboratory and greenhouse with zoospores or mycelia and incubated under high relative humidity (data not shown). The ability of the pathogen to infect diverse tissue types raises the possibility that the residues of Brassica spp. incorporated into the soil may sustain or increase $P$. capsici population densities in the field instead of reducing inoculum levels. P. capsici does not appear to be affected by glucosinolate compounds in Brassica tissue, and the disease reduction noted in previous studies using incorporated Brassica plant tissue to reduce P. capsici (Coelho et al. 1999; Cohen et al. 2008; Demirci and Dolar 2006; Ji et al. 2012; Ludwig et al. 2004; McGrath and Menasha 2013; Ppoyil 2011) may have been due to increases in antagonistic soil microorganisms (Mazzola et al. 2007; Wiggins and Kinkel 2005 ) or variations in $P$. capsici isolate sensitivity to the Brassica tissue and related volatile compounds (Morales-Rodriguez et al. 2014; Ppoyil 2011).

The difference in susceptibility of $B$. juncea Pacific Gold and Florida Broad Leaf suggests that tolerance to $P$. capsici may exist among Brassica spp. Field tolerance to $P$. capsici has been observed with other hosts such as Cucurbita pepo (Meyer and Hausbeck 2013) and Capsicum annuum (Foster and Hausbeck 2010), and host resistance is often considered an optimal disease management strategy (Granke et al. 2012; Ristaino and Johnston 1999). Using fungicides to keep biofumigant cover crops healthy is not desirable; therefore, screening Brassica cover crops for resistance to P. capsici isolates from diverse geographic locations is important. A similar screening has been successful in identifying tolerance in cauliflower to Phytophthora blight caused by P. megasperma (Hamm and Koepsell 1984; Kontaxis and Rubatzky 1983). Phytophthora spp. that affect Brassica vegetables have been observed during wet years or when fields with heavy soils that are prone to waterlogging are utilized (Tompkins et al. 1936). P. drechsleri and P. megasperma caused significant losses to Brassica crops both in the field (Hamm and Koepsell 1984; Thompson and Phillips 1988; Tompkins et al. 1936) and in storage (Geeson 1976; Geeson et al. 1990; Hermansen and Hoftun 2005), often after periods of soil saturation and wet conditions during harvest. The similarity of the reported symptoms of Phytophthora blight of Brassica vegetables to those observed in this study stresses the need for accurate identification of diseased plants. Fungicide recommendations have been made for controlling Phytophthora spp. on Brassica vegetables and include the systemic fungicide metalaxyl (Anonymous 1996; Kontaxis and Rubatzky 1983). However, widespread resistance to this fungicide and its racemic isomer, mefenoxam, have been reported for P. capsici (Hausbeck and Lamour 2004). Soil-directed fungicide applications of newer systemic fungicides are effective in controlling P. capsici root rots (Foster and Hausbeck 2010; Meyer and Hausbeck 2013) and trials are in progress to test the effectiveness of fungicides for management of $P$. capsici root rot of Brassica vegetables.

$P$. capsici has the potential to infect and cause significant losses on over 30,000 ha of susceptible vegetables grown annually in Michigan (Anonymous 2012), and uninfested land used for vegetable production that is available for rotation is becoming increasingly scarce (Hausbeck and Lamour 2004). The widespread utilization of Brassica spp. as vegetable crops and for biofumigation in vegetable production (Larsen 1980; Ngouajio and Mutch 2004; Snapp et al. 2006) and the prevalence of $P$. capsici in vegetable fields (Hausbeck and Lamour 2004) highlight the importance of conducting further studies into the etiology of this pathogen on Brassica spp. Even though severe disease was not observed on some of the vegetable crops tested in this study, roots infected at the subclinical level may enable survival of $P$. capsici in soil (Shishkoff 2007) and result in significant reductions in yield (Stanghellini and Kronland 1986). The identification of $P$. capsici as a potential pathogen of Brassica spp. and the ability to cause severe disease on the biofumigation cover crop Pacific Gold means that these crops should be monitored for Phytophthora root rot when planted into fields with a history of $P$. capsici. In addition, recommendations for Phytophthora blight prevention and management (Hausbeck and Lamour 2004) should be strongly adhered to when considering planting Brassica vegetables into infested fields.

\section{Acknowledgments}

We thank the Michigan Department of Agriculture and Rural Development Specialty Crop Block Grant Number 791N4300114, administered by the Michigan Vegetable Council, for the funding provided; and S. Linderman for technical assistance in editing tables and figures during the preparation of this manuscript.

\section{Literature Cited}

Ackroyd, V. J. 2010. Evaluation of spring-planted Brassica cover crops for use in muskmelon (Cucumis melo L.) and eggplant (Solanum melongena L.) production systems. M.S. thesis, Michigan State University, East Lansing.

Anonymous. 1996. EPPO Guidelines on good plant protection practices, Brassica vegetables. EPPO Bull. 26:311-347.

Anonymous. 2012. Census of Agriculture, Michigan 2012. U.S. Dep. Agric. Natl. Agric. Stat. Serv. Online publication. http://www.agcensus.usda.gov/Publications/ 2012/Full_Report/Volume_1, Chapter_1_State_Level/Michigan/

Anonymous. 2014. Mustard green manures on-farm research results measurement: shoot and root glucosinolate concentrations. Washington State University. Online publication. http://csanr.wsu.edu/pdfs/P1931.pdf

Baysal, F., and Miller, S. A. 2009. Effect of commercial biofumigant cover crops on growth, yield and disease of processing tomatoes. II International Symposium on Tomato Diseases. Acta Hortic. 808:117-120.

Charron, C. S., and Sams, C. E. 1999. Inhibition of Pythium ultimum and Rhizoctonia solani by shredded leaves of Brassica species. J. Am. Soc. Hortic. Sci. 124:462-467.

Clossais-Besnard, N., and Larher, F. 1991. Physiological role of glucosinolates in Brassica napus. Concentration and distribution pattern of glucosinolates among plant organs during a complete life cycle. J. Sci. Food Agric. 56:25-38.

Coelho, L., Chellemi, D. O., and Mitchell, D. J. 1999. Efficacy of solarization and cabbage amendment for the control of Phytophthora spp. in North Florida. Plant Dis. 83:293-299.

Cohen, M., Yamamoto, E., Condeso, E., Anacker, B., Rank, N., and Mazzola, M 2008. Microbial- and isothiocyanate-mediated control of Phytophthora and Pythium species. In: Proc. Sudden Oak Death Third Sci. Symp. Gen. Tech. Rep. PSW-GTR-214. U.S. Dep. Agric. For. Serv. Pac. Southwest Res. Stn. Albany, CA.

Demirci, F., and Dolar, F. S. 2006. Effects of some plant materials on Phytophthora blight (Phytophthora capsici Leon.) of pepper. Turk. J. Agric. For. 30:247-252.

Downes, M. J., and Loughnane, J. B. 1969. Phytophthora megasperma Drechsl. on broccoli and swede in Republic of Ireland. Plant Pathol. 18:48.

Enzenbacher, T. B. 2011. An evaluation of cucurbits and ornamentals for susceptibility to Phytophthora spp. M.S. thesis, Michigan State University, East Lansing.

Fahey, J. W., Zalcmann, A. T., and Talalay, P. 2001. The chemical diversity and distribution of glucosinolates and isothiocyanates among plants. Phytochemistry 56:5-51.

Fahn, A. 1982. The Epidermis. Pages 145-174 in: Plant Anatomy. Pergamon Press, Oxford.

Fan, C., Xiong, G., Qi, P., Ji, G., and He, Y. 2008. Potential biofumigation effects of Brassica oleracea var. caulorapa on growth of fungi. J. Phytopathol. 156: 321-325.

Foster, J. M., and Hausbeck, M. K. 2010. Managing Phytophthora crown and root rot in bell pepper using fungicides and host resistance. Plant Dis. 94:697-702.

French-Monar, R. D., Jones, J. B., and Roberts, P. D. 2006. Characterization of Phytophthora capsici associated with roots of weeds on Florida vegetable farms. Plant Dis. 90:345-350.

Gardiner, J. B., Morra, M. J., Eberlein, C. V., Brown, P. D., and Borek, V. 1999. Allelochemicals released in soil following incorporation of rapeseed (Brassica napus) green manures. J. Agric. Food Chem. 47:3837-3842.

Geeson, J. 1976. Storage rot of white cabbage caused by Phytophthora porri. Plant Pathol. 25:115-116.

Geeson, J., Browne, K., and McKeown, B. 1990. Storage rot of swede caused by Phytophthora sp. Plant Pathol. 39:629-631.

Gevens, A. J., Donahoo, R. S., Lamour, K. H., and Hausbeck, M. K. 2008. Characterization of Phytophthora capsici causing foliar and pod blight of snap bean in Michigan. Plant Dis. 92:201-209.

Glosier, B. R., Ogundiwin, E. A., Sidhu, G. S., Sischo, D. R., and Prince, J. P. 2008. A differential series of pepper (Capsicum annuиm) lines delineates 
fourteen physiological races of Phytophthora capsici-Physiological races of $P$. capsici in pepper. Euphytica 162:23-30.

Granke, L. L., Quesada-Ocampo, L. M., Lamour, K., and Hausbeck, M. 2012. Advances in research on Phytophthora capsici on vegetable crops in the United States. Plant Dis. 96:1588-1600.

Greenhalgh, J., and Mitchell, N. 1976. The involvement of flavour volatiles in the resistance to downy mildew of wild and cultivated forms of Brassica oleracea. New Phytol. 77:391-398

Hamm, P. B., and Koepsell, P. A. 1984. Phytophthora root-rot of cabbage and cauliflower in Oregon. Plant Dis. 68:533-535.

Hartman, G., and Huang, Y. 1993. Pathogenicity and virulence of Phytophthora capsici isolates from Taiwan on tomatoes and other selected hosts. Plant Dis. 77:588-591.

Hartwig, N. L., and Ammon, H. U. 2002. Cover crops and living mulches. Weed Sci. 50:688-699.

Hausbeck, M. K., and Lamour, K. H. 2004. Phytophthora capsici on vegetable crops: Research progress and management challenges. Plant Dis. 88:12921303.

He, H. J., Fingerling, G., and Schnitzler, W. H. 2003. Changes in glucosinolate concentrations during growing stages of tai tsai (Brassica campestris L. ssp. chinensis var. tai-tsai hort.) and potherb mustard (Brassica juncea Coss.). Acta Hortic. 620:77-84.

Hermansen, A., and Hoftun, H. 2005. Effect of storage in controlled atmosphere on post-harvest infections of Phytophthora brassicae and chilling injury in Chinese cabbage (Brassica rapa L. pekinensis (Lour) Hanelt). J. Sci. Food Agric. 85:1365-1370.

Ji, P., Koné, D., Yin, J., Jackson, K. L., and Csinos, A. S. 2012. Soil amendments with Brassica cover crops for management of Phytophthora blight on squash. Pest Manage. Sci. 68:639-644.

Kirkegaard, J. A., and Sarwar, M. 1998. Biofumigation potential of Brassicas-I. Variation in glucosinolate profiles of diverse field-grown Brassicas. Plant Soil 201:71-89.

Kontaxis, D. G., and Rubatzky, V. E. 1983. Phytophthora root rot in cauliflower. Calif. Agric. 37:12.

Lamour, K. H., and Hausbeck, M. K. 2000. Mefenoxam insensitivity and the sexual stage of Phytophthora capsici in Michigan cucurbit fields. Phytopathology 90:396-400.

Larkin, R. P., and Griffin, T. S. 2007. Control of soilborne potato diseases using Brassica green manures. Crop Prot. 26:1067-1077.

Larsen, P. 1980. Secondary plant products. Pages 501-525 in: The Biochemistry of Plants, Vol. 7. P. Stumpf. and E. Conn., eds. Academic Press, New York.

Lazzeri, L., and Manici, L. M. 2001. Allelopathic effect of glucosinolatecontaining plant green manure on Pythium sp. and total fungal population in soil. HortScience 36:1283-1289.

Lewis, J. A., and Papaviza, G. 1971. Effect of sulfur containing volatile compounds and vapors from cabbage decomposition on Aphanomyces eureiches. Phytopathology 61:208-214.

Ludwig, G. C., Goldberg, N. P., Remmenga, M., and Blackwell, L. 2004. Evaluation of Brassica crop residue effects on Verticillium wilt and Phytophthora root rot in chile peppers. (Abstr.) Phytopathology 94:S63.

Marschner, H. 1995. The soil-root interface in relation to mineral nutrition. Pages 537-541 in: Mineral Nutrition of Higher Plants, 2nd ed. Academic Press, New York.

Mattner, S., Porter, I., Gounder, R., Shanks, A., Wren, D., and Allen, D. 2008. Factors that impact on the ability of biofumigants to suppress fungal pathogens and weeds of strawberry. Crop Prot. 27:1165-1173.

Mayton, H. S., Olivier, C., Vaughn, S. F., and Loria, R. 1996. Correlation of fungicidal activity of Brassica species with allyl isothiocyanate production in macerated leaf tissue. Phytopathology 86:267-271.

Mazzola, M., Brown, J., Izzo, A. D., and Cohen, M. F. 2007. Mechanism of action and efficacy of seed meal-induced pathogen suppression differ in a Brassicaceae species and time-dependent manner. Phytopathology 97:454-460.

Mazzola, M., Brown, J., Zhao, X. W., Izzo, A. D., and Fazio, G. 2009. Interaction of Brassicaceous seed meal and apple rootstock on recovery of Pythium spp. and Pratylenchus penetrans from roots grown in replant soils. Plant Dis. 93: 51-57.

McGrath, M. T., and Menasha, S. R. 2013. Managing Phytophthora blight with biofumigation. (Abstr.) Phytopathology 103:S93.

McGregor, D. 1988. Glucosinolate content of developing rapeseed (Brassica napus L. 'Midas') seedlings. Can. J. Plant Sci. 68:367-380.

Meyer, M. D., and Hausbeck, M. K. 2013. Using soil-applied fungicides to manage Phytophthora crown and root rot on summer squash. Plant Dis. 97:107-112.
Morales-Rodriguez, C., Palo, C., Palo, E., and Rodriguez-Molina, M. C. 2014 Control of Phytophthora nicotianae with mefenoxam, fresh Brassica tissues, and Brassica pellets. Plant Dis. 98:77-83.

Morra, M., and Kirkegaard, J. 2002. Isothiocyanate release from soil-incorporated Brassica tissues. Soil Biol. Biochem. 34:1683-1690.

Muehlchen, A., Rand, R., and Parke, J. 1990. Evaluation of crucifer green manures for controlling Aphanomyces root rot of peas. Plant Dis. 74:651-654.

Ngouajio, M., and Mutch, D. 2004. Oilseed radish: A new cover crop for Michigan. Mich. State Univ. Ext. Bull. E-2907.

Nieuwhof, M. 1969. Cole Crops: Botany, Cultivation, and Utilization. World Crops Books. L. Hill, London.

Ppoyil, S. B. T. 2011. Effectiveness of mustard short-cycle cover crops for management of Phytophthora capsici and Fusarium spp. in cucurbits. M.S thesis, University of Illinois Urbana-Champaign.

Quesada-Ocampo, L. M., Fulbright, D. W., and Hausbeck, M. K. 2009. Susceptibility of Fraser Fir to Phytophthora capsici. Plant Dis. 93:135-141.

Quesada-Ocampo, L. M., and Hausbeck, M. K. 2010. Resistance in tomato and wild relatives to crown and root rot caused by Phytophthora capsici. Phytopathology 100:619-627.

Ristaino, J. B., and Johnston, S. A. 1999. Ecologically based approaches to management of Phytophthora blight on bell pepper. Plant Dis. 83:1080-1089.

Rosa, E. A. 1997. Daily variation in glucosinolate concentrations in the leaves and roots of cabbage seedlings in two constant temperature regimes. J. Sci. Food Agric. 73:364-368.

Rosa, E. A., Heaney, R. K., Portas, C. A., and Fenwick, G. R. 1996. Changes in glucosinolate concentrations in Brassica crops (B. oleracea and B. napus) throughout growing seasons. J. Sci. Food Agric. 71:237-244.

Sanogo, S., and Schaub, T. 2012. Evidence of inhibitory volatiles of London rocket and flixweed against three soilborne pathogens of chile pepper. (Abstr.) Phytopathology 102:S12.

Sarwar, M., and Kirkegaard, J. A. 1998. Biofumigation potential of Brassicas-II Effect of environment and ontogeny on glucosinolate production and implications for screening. Plant Soil 201:91-101.

Satour, M. M., and Butler, E. E. 1967. A root and crown rot of tomato caused by Phytophthora capsici and P. parasitica. Phytopathology 57:510-515.

Satour, M. M., and Butler, E. E. 1968. Comparative morphological and physiological studies of progenies from intraspecific matings of Phytophthora capsici. Phytopathology 58:183-192.

Saxton, A. M. 1998. A macro for converting mean separation output to letter groupings in Proc Mixed. Pages 1243-1245 in: 23rd SAS Users Group Int SAS Institute, Nashville, TN.

Semb, L. 1969. A rot of stored cabbage caused by a Phytophthora sp. Symposium on Vegetable Storage. Acta Hortic. 20:32-35.

Shishkoff, N. 2007. Persistence of Phytophthora ramorum in soil mix and roots of nursery ornamentals. Plant Dis. 91:1245-1249.

Smolinska, U., and Horbowicz, M. 1999. Fungicidal activity of volatiles from selected cruciferous plants against resting propagules of soil-borne fungal pathogens. J. Phytopathol. 147:119-124.

Smolinska, U., Morra, M., Knudsen, G., and Brown, P. 1997. Toxicity of glucosinolate degradation products from Brassica napus seed meal toward Aphanomyces euteiches f. sp. pisi. Phytopathology 87:77-82.

Snapp, S., Date, K., Cichy, K., and O’Neil, K. 2006. Mustards-A Brassica cover crop for Michigan. Mich. State Univ. Ext. Bull. E-2956.

Stanghellini, M. E., and Kronland, W. C. 1986. Yield loss in hydroponically grown lettuce attributed to subclinical infection of feeder rootlets by Pythium. dissotocum. Plant Dis. 70:1053-1056.

Sundermeier, A. 2008. Oilseed radish cover crop. Ohio State Univ. Wood County, Ohio. Fact Sheet SAG-5-08

Thompson, A., and Phillips, A. 1988. Root rot of cabbage caused by Phytophthora drechsleri. Plant Pathol. 37:297-299.

Tian, D., and Babadoost, M. 2004. Host range of Phytophthora capsici from pumpkin and pathogenicity of isolates. Plant Dis. 88:485-489.

Tompkins, C. M., Tucker, C. M., and Gardner, M. W. 1936. Phytophthora root rot of cauliflower. J. Agric. Res. 53:685-692.

Wang, Q., Ma, Y., Yang, H., and Chang, Z. 2014. Effect of biofumigation and chemical fumigation on soil microbial community structure and control of pepper Phytophthora blight. World J. Microbiol. Biotechnol. 30:507-518.

Waterhouse, G. M. 1963. Key to the species of Phytophthora de Bary. Mycol. Pap. 92:1-22.

Wiggins, E., and Kinkel, L. L. 2005. Green manures and crop sequences influence alfalfa root rot and pathogen inhibitory activity among soil-borne streptomycetes. Plant Soil 268:271-283. 